\title{
NEW BOUNDS ON ZAGREB INDICES
}

\section{ZHONGZHU LiU, QINGHUA MA AND YIZHi CHEN}

\begin{abstract}
The Zagreb indices are among the oldest and the most famous topological molecular structure-descriptors. The first Zagreb index is equal to the sum of the squares of the degrees of the vertices, and the second Zagreb index is equal to the sum of the products of the degrees of pairs of adjacent vertices of the respective graph. In this paper, we characterize the extremal graphs with maximal, second-maximal, third-maximal, fourth-maximal and minimal, secondminimal, third-minimal Zagreb indices among all Eulerian graphs, and then we give the tight conditions on the Zagreb indices of a graph for the existence of a spanning eulerian subgraph, dominating circuits, spanning circuits, Hamiltonian paths and cycles, respectively.
\end{abstract}

Mathematics subject classification (2010): 05C07, 05 C45.

Keywords and phrases: Zagreb index, Eulerian graph, supereulerian graph, dominating circuit, spanning circuit, Hamiltonian.

\section{REFERENCES}

[1] T. van Aardenne-Ehrenfest, And N. G. De Bruijn, Circuits and trees in oriented graphs, Simon Stevin 28, (1951) 203-217.

[2] N. L. Biggs, E. K. Lloyd, R. J. Wilson, Graph Theory, Clarendon Press, Oxford, 1976, pp. 1736-1936.

[3] A. Benhocine, L. Clark, N. Köhler, H. J. Veldman, On circaits and pancyclic line graphs, J. Graph Theory 10, (1986) 411-425.

[4] A. T. Balaban, I. Motoc, D. Bonchev, O. Mekenyan, Topological indices for structureactivity corrections, Topics Curr. Chem. 114 (1983) 21-55.

[5] M. Bianchi, A. Cornaro, J. L. Palacios, A. Torriero, New bounds of degree-based topological indices for some classes of c-cyclic graphs, Discr. Appl. Math. 194 (2015) 62-75.

[6] B. BoroviĆANIN, On the extremal Zagreb indices of trees with given number of segments or given number of branching vertices, MATCH Commun. Math. Comput. Chem. 74 (2015) 57-79.

[7] B. BOROVIĆANin, T. AleKsić LAMPERT, On the maximum and minimum Zagreb indices of trees with a given number of vertices of maximum degree, MATCH Commun. Math. Comput. Chem. $\mathbf{7 4}$ (2015) 81-96.

[8] F. T. Boesch, C. Suffel, R. Tindell, The spanning subgraphs of Eulerian graphs, J. Graph Theory 1 (1977) 79-84.

[9] H. J. Broersma, Liming Xiong, A note on minimum degree conditions for supereulerian graphs, Discrete Applied Mathematics 120 (2002) 35-43.

[10] S. Chen, W. LiU, Tricyclic graphs with minimum modified Schultz index and maximum Zagreb indices, Ars Comb. 122 (2015) 379-397.

[11] D. DE CAEN, An upper bound on the sum of squares of degrees in a graph, Discr. Math. 185 (1998) 245-248.

[12] P. CATLin, Supereulerian graph: a survey, J. Graph Theory 16 (1992) 177-196.

[13] Z. H. Chen, H. J. LAI, Supereulerian graphs and the Petersen graph II, ARS Combinatoria 48, (1998) 271-282.

[14] Z. H. CHEN, H. J. LAI, Reduction techniques for supereulerian graphs and related topics an update, Combinatorics and Graph Theory $\mathbf{9 5}$, ed. by Ku Tung-Hsin, World Scientific, Singapore/London (1995) pp. 53-69. 
[15] K. C. Das, I. Gutman, Some properties of the second Zagreb index, MATCH Commun. Math. Comput. Chem. 52 (2004) 103-112.

[16] H. DENG, A unified approach to the extremal Zagreb indices for trees, unicyclic graphs and bicyclic graphs, MATCH Commun. Math. Comput. Chem. 57 (2007) 597-616.

[17] M. FiedLER, V. NiKIFOROV, Spectral radius and Hamiltonicity of graphs, Linear Algebra Appl. 432 (2010), 2170-2173.

[18] I. Gutman, R. Cruz, J. Rada, Wiener index of Eulerian graphs, Discrete Applied Mathematics 162 (2014) 247-250.

[19] I. Gutman, K. C. DAs, The first Zagreb index 30 years after, MATCH Commun. Math. Comput. Chem. 50 (2004) 83-92.

[20] I. Gutman, B. Ruščić, N. TRinajstić, C. F. WilcoX, Graph theory and molecular orbitals, XII. Acyclic polyenes, J. Chem. Phys. 62 (1975), 3399-3405.

[21] I. Gutman, N. TRInAJstić, Graph theory and molecular orbitals, Total $\pi$ electron energy of alternant hydrocarbons, Chem. Phys. Lett. 17 (1972) 535-538.

[22] I. Gutman, M. K. JAMIL, N. AKHTER, Graphs with fixed number of pendent vertices and minimal first Zagreb index, Trans. Comb. 4 (2015) 43-48.

[23] S. M. Hosamani, B. Basavanagoud, New upper bounds for the first Zagreb index, MATCH Commun. Math. Comput. Chem. 74 (2015) 97-101.

[24] A. Ilić, D. Stevanović, On comparing zagreb indices, MATCH Commun. Math. Comput. Chem. 62 (2009), 681-687.

[25] H. J. LaI, H. Yan, Super Eulerian graphs and matchings, Applied Mathematics Letters 24 (2011) 1867-1869.

[26] E. Milovanović, I. Milovanović, Sharp bounds for the first Zagreb index and first Zagreb coindex, Miskolc Math. Notes, 16 (2015) 1017-1024.

[27] S. Nikolić, G. KovaČEvić, Ante MiličEvić, N. TRinajstić, The Zagreb indices 30 years after, Croat. Chem. Acta., 76 (2), (2003), 113-124.

[28] O. ORE, Note on Hamilton circuits, Amer. Math. Monthly 67 (1960), 55.

[29] W. R. Pulleyblank, A note on graphs spanned by Eulerian graphs, J. Graph Theory, 3 (1979) 309-310.

[30] R. Todeschini, V. Consonni, Handbook of Molecular Descriptors, Wiley-VCH, Wein-heim, 2000.

[31] J. F. WANG, F. Belardo, A lower bound for the first Zagreb index and its application, MATCH Commun. Math. Comput. Chem. 74 (2015) 35-56.

[32] Z. YAN, H. LiU, H. LiU, Sharp bounds for the second Zagreb index of unicyclic graphs, J. Math. Chem., 42 (2007) 565-574.

[33] H. ZHANG, S. ZHANG, Uncyclic graphs with the first three smallest and largest first general Zagreb index, MATCH Commun. Math. Comput. Chem., 55 (2006) 427-438.

[34] B. ZHou, Zagreb indices, MATCH Commun. Math. Comput. Chem., 52 (2004) 113-118.

[35] B. ZHOU, Signless Laplacian spectral radius and Hamiltonicity, Linear Algebra Appl. 432 (2010), $566-570$. 